\title{
Space-based evaluation of interactions between aerosols and low-level Arctic clouds during the Spring and Summer of 2008
}

\author{
K. Tietze ${ }^{1, \dagger}$, J. Riedi ${ }^{2}$, A. Stohl ${ }^{3}$, and T. J. Garrett ${ }^{1}$ \\ ${ }^{1}$ Department of Atmospheric Sciences, University of Utah, Salt Lake City, UT, USA \\ ${ }^{2}$ Laboratoire d'Optique Atmosphérique, Université de Lille1/CNRS, France \\ ${ }^{3}$ Norwegian Institute for Air Research, Kjeller, Norway \\ ${ }^{\dagger}$ deceased
}

Received: 2 November 2010 - Published in Atmos. Chem. Phys. Discuss.: 26 November 2010

Revised: 4 March 2011 - Accepted: 29 March 2011 - Published: 8 April 2011

\begin{abstract}
This study explores the indirect effects of anthropogenic and biomass burning aerosols on Arctic clouds by co-locating a combination of MODIS and POLDER cloud products with output from the FLEXPART tracer transport model. During the activities of the International Polar Year for the Spring and Summer of 2008, we find a high sensitivity of Arctic cloud radiative properties to both anthropogenic and biomass burning pollution plumes, particularly at air temperatures near freezing or potential temperatures near $286 \mathrm{~K}$. However, the sensitivity is much lower at both colder and warmer temperatures, possibly due to increases in the wet and dry scavenging of cloud condensation nuclei: the pollution plumes remain but the component that influences Arctic clouds has been removed along transport pathways. The analysis shows that, independent of local temperature, cloud optical depth is approximately four times more sensitive to changes in pollution levels than is cloud effective radius. This suggests that some form of feedback mechanism amplifies the radiative response of Arctic clouds to pollution through changes in cloud liquid water path.
\end{abstract}

\section{Introduction}

Every winter and spring, the lower Arctic troposphere fills with elevated concentrations of foreign pollutants. The first formal studies of the phenomenon were made by European explorers over a century ago (Garrett and Verzella, 2008). More recent work has shown that the primary source of these pollutants is the long-range transport of anthropogenic

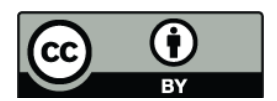

Correspondence to: T. J. Garrett (tim.garrett@utah.edu) and biomass burning emissions from lower latitudes (Shaw, 1982; Quinn et al., 2007; Fisher et al., 2010; Warneke, 2010). A persistent wintertime surface temperature inversion inhibits vertical mixing and turbulent aerosol deposition, and the dryness of the Arctic atmosphere results in minimal wet scavenging (Law and Stohl, 2007). The Arctic haze rapidly dissipates in the spring, primarily due to the increased efficiency of wet scavenging in the warmer weather, although reduced transport efficiency from mid-latitudes also plays a role (Garrett et al., 2010; Huang et al., 2010; Matsui et al., 2011).

Aerosols transported to the Arctic from lower latitudes can act as Cloud Condensation Nuclei (CCN). Enhanced CCN levels can increase cloud droplet number concentrations and decrease average droplet size relative to cleaner conditions (Hobbs et al., 2000). Over dark oceans, this can make clouds brighter and therefore have a cooling effect (Twomey, 1977). However, surface cooling is thought to be small in the Arctic due to low pollution levels during the summer and a generally highly reflective surface (Garrett et al., 2002). A more significant aerosol indirect effect involves changes in cloud thermal emission. Thin low level clouds have increased thermal emissivity under polluted conditions so that enhanced levels of CCN can possibly have a significant warming effect (Lubin and Vogelmann, 2006; Garrett and Zhao, 2006; Mauritsen et al., 2011).

Additionally, elevated aerosol concentrations have been thought to affect precipitation and cloud lifetime. Smaller droplet sizes suppress the collision coalescence processes responsible for warm rain initiation, increasing the cloud water content and lengthening the lifetime of the cloud (Albrecht, 1989; Radke et al., 1989; Kaufman et al., 2005). However, further studies have shown that due to a myriad of

Published by Copernicus Publications on behalf of the European Geosciences Union. 
dynamical considerations, there is no simple association between aerosol concentrations, precipitation and cloud liquid water content (Durkee et al., 2000; Ackerman et al., 2004; Lu and Seinfeld, 2005; Stevens and Feingold, 2009). For example, Xue and Feingold (2006) used model simulations to find that, although elevated aerosol concentrations tend to suppress precipitation, there is also an overall reduction in cloudiness due to stronger evaporation of the smaller cloud droplets and an increase in the entrainment of dry air.

For a comprehensive examination of aerosol-cloud interactions, space based measurements can be particularly useful since they provide sufficient statistics to tease a weak signal from a naturally noisy system. However, one downside of using passive spaceborne measurements alone to study aerosolcloud interactions is that it is not possible to study clouds and aerosols that are vertically and horizontally coincident since clouds are normally orders of magnitude brighter. For example, a commonly employed strategy is to pair cloud retrievals with aerosol retrievals from nearby adjacent airmasses. The implicit assumption is that aerosol concentrations are horizontally homogeneous so that the two retrievals can be meaningfully compared (Sekiguchi et al., 2003; Quaas et al., 2004; Kaufman et al., 2005).

What is perhaps preferable is to examine the pollution field from a tracer transport model with cloud properties from colocated satellite measurements (e.g., Avey et al., 2007 and Brioude et al., 2009). While this method relies on the accuracy of the transport model, the major advantage of this approach is that the cloud and pollution fields can be compared under the same meteorological conditions. Also, if the model pollution tracer is strictly passive within dynamic flows, it can be treated as an independent quantity that is unaffected by clouds, chemical processes and precipitation removal. Avey et al. (2007) used this method to study pollution-cloud interactions off the eastern seaboard of the United States. The comparison showed that the sensitivity of cloud effective radius and optical depth to anthropogenic pollution plumes decreases with increasing distance from emission sources. It was inferred that wet scavenging had removed cloud active aerosol particles, leaving the inactive components of the pollution plumes behind.

Arctic haze has traditionally been attributed to plumes of anthropogenic pollution coming from Eurasian industrial activity north of the Arctic front (Shaw, 1995). However, recent studies of large summertime Boreal forest fires in North America (Stohl et al., 2006) and eastern European fires occurring in the Spring of 2006 (Stohl et al., 2007) arrived at the conclusion that biomass burning has been largely underestimated as a source of Arctic haze and aerosols. In fact, both anthropogenic and biomass burning pollution plumes were a primary focus of the International Polar Year (IPY) of 2007 and 2008 activities in the Arctic (Stohl, 2005). IPY field campaigns and aircraft experiments concurrent with the period of this study give a wider context for the results presented here (Ghan et al., 2007; Jacob et al., 2010).
Here, we adopt a similar approach to Avey et al. (2007) for analysis of the effects of anthropogenic and biomass burning pollution on Arctic clouds for the period 21 March through 21 July, corresponding to several IPY studies taking place during the transition from the highly polluted winter to the relatively clean summer (Paris et al., 2008; Jacob et al., 2010).

\section{Methods}

The effect of aerosols on cloud optical depth through changes in droplet size, or the first aerosol indirect effect, is typically quantified using the Indirect Effect parameter (IE). Normally, IE is defined by the relative change in a cloud property, generally cloud optical depth $(\tau)$ or cloud droplet effective radius $\left(r_{\mathrm{e}}\right)$, with respect to a relative change in some aerosol quantity, often satellite retrieved aerosol optical depth $\left(\tau_{\mathrm{a}}\right)$ (Feingold et al., 2001; Bréon et al., 2002; Lohmann and Feichter, 2005), e.g.

$\mathrm{IE}_{\mathrm{re}}=-\frac{d \ln r_{\mathrm{e}}}{d \ln \tau_{\mathrm{a}}}$

An alternative approach is to evaluate the IE parameter with respect to fields of some passive pollution tracer that does not interact with clouds. A good choice here is carbon monoxide (CO) tracer concentrations produced by a Lagrangian dispersion model. Close to emission sources, anthropogenic $\mathrm{CO}$ generally correlates well with anthropogenic $\mathrm{CCN}$ in a non-precipitating air-mass (Longley et al., 2005). In the Arctic, when precipitation is low, the ratio of aerosol light scattering to short-term $\mathrm{CO}$ perturbations is centered around a mode value of $0.4 \mathrm{Mm}^{-1} \mathrm{ppb}^{-1}$ (Garrett et al., 2010). Unlike CCN, however, the $\chi_{\mathrm{CO}}$ tracer is merely passive, and it is affected only by dilution. It does not interact with or influence clouds. In order to focus on the variability contributions associated with long-range transport to the Arctic, FLEXPART instantly removes all CO that has had twenty days atmospheric residence time.

The advantage of comparing a passive pollution tracer to cloud fields is that pollution and clouds are not coupled through the effects of clouds on aerosols. This permits identification of cause and effect in pollution-cloud interactions. For example, if concentrations of $\chi_{\mathrm{CO}}$ are high but the colocated cloud perturbations are low, this may be interpreted as an indication that $\mathrm{CCN}$, the cloud active components of the pollution field, have been removed through wet scavenging (Avey et al., 2007).

To explain further, since, cloud optical depth $(\tau)$ can be expressed as

$\tau=\frac{3}{2} \frac{\mathrm{LWP}}{\rho_{w} r_{\mathrm{e}}}$ 
Table 1. Cloud products and pollution tracer used in the study

\begin{tabular}{lll}
\hline Source & Parameter & Reference \\
\hline MODIS-Aqua & $\begin{array}{l}\text { Cloud top temperature }\left(T_{\mathrm{C}}\right) \\
\text { Cloud optical depth }(\tau)\end{array}$ & \\
& $\begin{array}{l}\text { Droplet effective radius }\left(r_{\mathrm{e}}\right) \\
\text { Cloud pressure }\left(P_{\mathrm{O}_{2}}\right)\end{array}$ & $\begin{array}{l}\text { (King et al., 2005) } \\
\text { (Fougnie et al., 2007) }\end{array}$ \\
MODIS-POLDER & Cloud phase index $(\phi)$ & (Riedi et al., 2010) \\
FLEXPART & Anthropogenic \& biomass burning tracer $\left(\chi_{\mathrm{CO}}\right)$ & $($ Stohl et al., 2005, 2007) \\
\hline
\end{tabular}

where $\rho_{w}$ is the bulk density of liquid water, the derivative of the natural logarithm of $\tau$ with respect to the logarithm of the $\chi_{\mathrm{CO}}$ tracer, is

$$
\frac{d \ln \tau}{d \ln \chi_{\mathrm{CO}}}=-\frac{d \ln r_{\mathrm{e}}}{d \ln \chi_{\mathrm{CO}}}+\frac{d \ln \mathrm{LWP}}{d \ln \chi_{\mathrm{CO}}}
$$

Since, CCN are the active components of pollution plumes, the sensitivity of cloud optical depth to pollution will be product of two partial derivatives evaluated in the following manner:

$$
\frac{d \ln \tau}{d \ln \chi_{\mathrm{CO}}}=\frac{d \ln \tau}{d \ln \mathrm{CCN}} S
$$

where

$$
S=\frac{d \ln \mathrm{CCN}}{d \ln \chi_{\mathrm{CO}}}
$$

is a scavenging parameter that ranges from 0 to 1 (Garrett et al., 2006, 2010). When the rate of wet scavenging is high then $S$ will be small, indicating a small relative change in $\mathrm{CCN}$ for a relative change in $\chi_{\mathrm{CO}}$. Conversely, $S$ is large when minimal amounts of wet scavenging have impacted the pollution plume and the correlation between $\mathrm{CCN}$ and $\chi_{\mathrm{CO}}$ is high.

While cloud microphysical properties can be influenced by aerosols, they are more fundamentally determined by the meteorological conditions in which they form (Chang and Coakley, 2007). To first order, the amount of liquid water in an adiabatic cloud depends on the difference in moist and dry lapse rates at a certain temperature and pressure according to the basic thermodynamic relationship;

$$
\frac{d \mathrm{LWC}}{d z}=\frac{\rho_{\mathrm{a}}(T, P) C_{p}}{L_{\mathrm{v}}}\left(\Gamma_{\mathrm{d}}-\Gamma_{\mathrm{s}}(T, P)\right)
$$

where, $\rho_{\mathrm{a}}$ is the air density, $C_{p}$ is the heat capacity of air, $L_{\mathrm{V}}$ the latent heat of vaporization, $\Gamma_{\mathrm{d}}$ the dry adiabatic lapse rate and $\Gamma_{s}$ the moist adiabatic lapse rate. At colder temperatures the difference in lapse rates is much smaller and consequently less moisture is available for condensation and release of latent heat. For example, a cloud forming at $900 \mathrm{hPa}$ at a temperature of $-15^{\circ} \mathrm{C}$ will have a value of $d \mathrm{LWC} / d z$ of $0.7 \mathrm{~g} \mathrm{~m}^{-3} \mathrm{~km}^{-1}$. At the same height but a temperature of $0{ }^{\circ} \mathrm{C}, d \mathrm{LWC} / d z$ has a value of approximately $1.9 \mathrm{~g} \mathrm{~m}^{-3} \mathrm{~km}^{-1}$.

Thus, in order to limit meteorological bias and constrain cloud microphysical sensitivity to pollution, we evaluate the sensitivity of cloud properties to $\chi_{\mathrm{CO}}$ within small bins of temperature and pressure. This minimizes covariance associated with $\chi_{\mathrm{CO}}$ acting as a tracer of warmer, moister, airmasses that may be influencing the observed cloud properties more than pollution itself.

Furthermore, we examine only low-level, liquid clouds in the Arctic, in order to simplify interpretation of the physics and to ease comparison with prior studies that have examined the sensitivity of clouds to pollution aerosols (Garrett et al., 2004; Garrett and Zhao, 2006; Lubin and Vogelmann, 2006; Mauritsen et al., 2011). The effects of aerosols on mixedphase clouds is a more complex issue (Curry et al., 1996; Girard et al., 2005; Morrison and Pinto, 2005; Morrison et al., 2008; de Boer et al., 2009) and not directly addressed in this study.

Here, we calculate the values of $\mathrm{IE}_{\mathrm{re}}, \mathrm{IE}_{\tau}$, and $\mathrm{IE}_{\mathrm{LWP}}$, by fitting a linear least squares regression of the natural logarithm of the cloud properties against the natural logarithm of the combined anthropogenic and biomass burning tracers, for a given pressure level and temperature. Thus

$$
\begin{aligned}
& \mathrm{IE}_{\mathrm{re}}=-\left.\frac{d \ln r_{\mathrm{e}}}{d \ln \chi_{\mathrm{CO}}}\right|_{T, P} \\
& \mathrm{IE}_{\tau}=\left.\frac{d \ln \tau}{d \ln \chi_{\mathrm{CO}}}\right|_{T, P} \\
& \mathrm{IE}_{\mathrm{LWP}}=\left.\frac{d \ln \mathrm{LWP}}{d \ln \chi_{\mathrm{CO}}}\right|_{T, P}
\end{aligned}
$$

\section{Data products used}

In order to characterize pollution-cloud interactions, we use a combination of satellite retrieved cloud products and a modeled pollution tracer, as summarized in Table 1 . The cloud 
products are retrieved using the MODIS and POLDER instruments on A-train satellites Aqua and PARASOL (Polarization and Anisotropy of Reflectances for Atmospheric Sciences coupled with Observations from a Lidar), respectively. The tracer transport model FLEXPART provides a tracer for anthropogenic emissions along with a tracer of biomass burning.

\subsection{Cloud products}

Aqua MODIS Collection 5 Level-2 retrievals, are used to provide cloud-top effective radius $\left(r_{\mathrm{e}}\right)$, temperature $\left(T_{\mathrm{C}}\right)$ and optical depth $(\tau)$ (Platnick et al., 2003; King et al., 2005). The retrieval of $r_{\mathrm{e}}$ is made using simultaneous measurements of cloud reflectance from the water absorbing bands (1.6, 2.1, $3.7 \mu \mathrm{m}$ ) combined with one of the non (or less) absorbing bands $(0.65,0.86,1.2 \mu \mathrm{m})$ depending on the surface conditions. MODIS airborne simulator $r_{\mathrm{e}}$ values in stratiform cloud agree well with in situ measurements of liquid clouds in the Arctic (Platnick et al., 2003). Cloud Liquid Water Path (LWP) is acquired from the MODIS retrieved $r_{\mathrm{e}}$ and $\tau$ parameters from Eq. (2).

Flying just two minutes behind Aqua in the A-train constellation is the microsatellite PARASOL with the innovative radiometer/polarimeter POLDER (Polarization and Directionality of the Earth's Reflectance) that provides systematic measurements of spectral, directional and polarized characteristics of reflected sunlight (Fougnie et al., 2007). This unique multidirectional instrument provides cloud microphysical and macrophysical parameters at a spatial resolution close to $20 \times 20 \mathrm{~km}$.

Here, cloud pressure is determined from the POLDER cloud oxygen pressure $\left(P_{\mathrm{O}_{2}}\right)$, which is based on the differential absorption measured at 763 and $765 \mathrm{~nm}$ wavelength, corresponding to the A-band region of strong absorption by atmospheric oxygen (Bréon and Colzy, 1999). Multiple scattering in cloud places $P_{\mathrm{O}_{2}}$ values more towards the center of the cloud rather than cloud top. Nonetheless, $P_{\mathrm{O}_{2}}$ cloud top pressure from POLDER is preferred over MODIS cloud top pressure retrievals because the $P_{\mathrm{O}_{2}}$ algorithm does not utilize infrared channels that require an assumed temperature profile (Buriez et al., 1997; Weisz et al., 2007). Further discussion on this point is described in Sect. 3.3. We find that for lowlevel clouds in the Arctic, MODIS retrievals of cloud heights can be several kilometers too high.

With respect to detection of cloud phase, angular polarization features of shortwave radiation reflected off clouds depend strongly on particle shape, and POLDER captures a polarization signature unique to water droplets but absent in ice (Goloub et al., 2000). One of the MODIS phase retrievals makes use of the strong differences in the spectral absorption characteristics of ice and water in the $8.5 \mu \mathrm{m}$ and $11 \mu \mathrm{m}$ radiation bands (Platnick et al., 2003). An additional MODIS phase retrieval uses measurements of shortwave infrared reflectance (SWIR) at the wavelengths 1.6 and $2.1 \mu \mathrm{m}$ and re- flectance in the visible channels (King et al., 2003), taking advantage of the fact that ice particles are slightly more absorbing at SWIR wavelengths than liquid water droplets. While each retrieval has it's own set of advantages and limitations, the A-train allows the POLDER and MODIS products to be combined synergistically to provide a semi-continuous confidence index for thermodynamic phase $(\phi)$ ranging from confident liquid (Eq. 1) to confident ice (200) (Riedi et al., 2010).

Here, clouds with a value of $\phi$ that is 50 or below are assumed to be liquid because this threshold requires that at least two of the three phase retrieval algorithms used in the index agree.

\subsection{Anthropogenic and biomass burning pollution tracer}

The Lagrangian particle dispersion model FLEXPART (Stohl et al., 2005) is used here to characterize the transport of pollution into the Arctic, represented by $\mathrm{CO}$ concentrations fields $\left(\chi_{\mathrm{CO}}\right)$ from recent $(<20$ days old $)$ anthropogenic combustion and biomass burning emissions. The model is driven by the European Centre for Medium Range Weather Forecasts (ECMWF) operational analyses at a resolution of $0.5^{\circ} \times 0.5^{\circ}$ (White, 2002) and was set to produce pollution tracer output at 15 tropospheric vertical model levels, with a global horizontal resolution of $0.5^{\circ} \times 0.5^{\circ}$ in three hour time steps. FLEXPART calculates the trajectories of tracer particles using the mean winds interpolated from the meteorological analysis fields plus parametrized random motions representing turbulence and convection (Stohl and Thomson, 1999).

Anthropogenic emission sources are calculated from the EDGAR emission inventory outside North America (Olivier and Berdowski, 2001). For North America, emissions were calculated from Frost et al., 2006. A tracer of biomass burning is incorporated into the model based on a fire detection scheme from the MODIS instruments on Aqua and Terra (Giglio et al., 2003) and using an algorithm described by Stohl et al. (2007).

The FLEXPART model has been a popular choice for understanding the origins and characteristics of Arctic air pollution (Stohl et al., 2007; Law and Stohl, 2007; Stohl, 2006). During the IPY airborne field experiments, ARCTAS (Arctic Research of the Composition of the Troposphere from Aircraft and Satellites) and ARCPAC (Aerosol, Radiation, and Cloud Processes affecting Arctic Climate), FLEXPART was used to predict locations of pollution plumes in order to select appropriate flight plans for in situ pollution measurements (Fuelberg et al., 2010; Jacob et al., 2010). Not only were pollution plume locations accurate, but, on average, predicted $\mathrm{CO}$ enhancements were within $30 \%$ of coincident airborne measurements (Warneke et al., 2010). Similar agreement has been seen in mid-latitude pollution plumes (Stohl et al., 2003, 2007). Some of this error is likely due to the limited sample 
volumes of aircraft measurements and would be lower for grid-cell averaged data. Comparisons with space-based retrievals of $\mathrm{CO}$ for Arctic pollution plumes indicate a low bias for FLEXPART CO (which may also be due to retrieval errors and is not important for this study) but otherwise agreement of CO columns to within some 10\% (see Fig. 8 in Sodemann et al., 2010).

\subsection{Co-location of cloud products with FLEXPART}

Here, we examine the entire Arctic region between $65^{\circ} \mathrm{N}$ and $84^{\circ} \mathrm{N}$, subject to satellite retrieval constraints. The orientation of the polar orbiting satellites means that the largest sampling density (approximately $42 \%$ ) lies between $70^{\circ} \mathrm{N}$ and $75^{\circ} \mathrm{N}$, including a large portion of land mass, some sea ice in the early part of the study, and open ocean in later part.

Satellite retrieved cloud properties from POLDER and MODIS are provided at different spatial resolutions. For a nadir view, MODIS cloud products are provided at $1 \mathrm{~km} \times 1 \mathrm{~km}$ resolution for $\tau$ and $r_{\mathrm{e}}$, while $T_{\mathrm{c}}$ is provided at $5 \mathrm{~km} \times 5 \mathrm{~km}$ resolution. The POLDER $P_{\mathrm{O}_{2}}$ pressure is derived from $6 \mathrm{~km} \times 6 \mathrm{~km}$ resolution observations but it is provided at a fixed resolution of $20 \mathrm{~km} \times 20 \mathrm{~km}$. The synergistic POLDER-MODIS cloud phase product is derived and provided at the full POLDER native resolution of $6 \mathrm{~km} \times 6 \mathrm{~km}$.

Prior to co-location with the FLEXPART tracer fields, all satellite cloud products are spatially co-located on a fixed resolution sinusoidal grid (equal area) of $6 \mathrm{~km} \times 6 \mathrm{~km}$ to maintain phase information at its highest resolution. Next, these merged POLDER and MODIS cloud products are temporally and spatially co-located with FLEXPART output. We match the A-train satellite overpass time to the appropriate FLEXPART tracer field, which is output every three hours. For example, a 08:33 UTC satellite overpass will be matched up with the 09:00 UTC FLEXPART pollution tracer fields, which represent an average of tracer concentrations between 06:00 and 09:00 UTC for that particular grid cell.

Establishing the vertical location of both aerosols and clouds is the best way to be able to determine if the two quantities are interacting on a microphysical level consistent with the aerosol indirect effect. For clouds forming in the tropical and subtropical marine boundary layer, the MODIS operational Collection Five cloud top pressure retrieval has been known to overestimate cloud top heights by 1 to $3 \mathrm{~km}$ (Holz et al., 2008). The bias is likely a result of problems the algorithm has in matching the observed $11 \mu \mathrm{m}$ brightness temperature to a unique atmospheric level in the presence of a strong subsidence temperature inversion. If a bias this large is similarly present in Arctic low-level cloud measurements, the ability to diagnose aerosol-cloud interactions using our analysis technique would be seriously compromised when using MODIS cloud top height retrievals. The Arctic is not subject to the same large scale subsidence of subtropical regions. However, strong temperature inversions are often present (Shupe et al., 2006) possibly affecting MODIS cloud top height retrievals.

The synergy of the A-train satellite group allows retrievals from different active and passive instruments to be meaningfully compared. As an alternative to the MODIS instrument, the POLDER cloud top height algorithm offers a very similar footprint and spatial resolution but it uses measurements from visible rather than infrared wavelength channels (Bréon and Colzy, 1999), eliminating the need for an estimated temperature profile in cloud placement determination.

We performed an inter-comparison of MODIS, POLDER and CALIOP cloud top heights in order to determine whether a bias affecting MODIS cloud top height retrievals of Arctic low-level clouds was present, and whether the POLDER algorithm offered any improvement. Cloud top heights from the three instruments were compared for multiple scenes of low-level stratiform clouds forming in the Arctic region spanning April to July 2008. Figure 1 shows an example of MODIS, POLDER and CALIOP cloud top height retrievals, co-located along the CALIOP footprint, and plotted with the vertical profile of modeled biomass burning and anthropogenic pollution tracer output. MODIS cloud top heights correspond to pollution tracer concentrations that are considerably different than the layer where the CALIOP Lidar and POLDER cloud top height retrievals indicate the cloud actually lies. For the low-level Arctic stratiform clouds that were compared, MODIS cloud top heights were found to have a consistent bias of $+1.6 \pm 0.5 \mathrm{~km}$ compared to POLDER and CALIOP. Note too, that unlike the MODIS tops, the POLDER/CALIOP cloud tops demarcate a boundary that is consistent with a familiar situation where dry polluted air overrides a moister cloud-topped boundary layer. For the purposes of this study, the reason for using POLDER rather than CALIOP data for matching cloud fields to FLEXPART data is that POLDER has a much larger footprint and swath, which provides much higher statistical representativeness.

The scheme for horizontal and vertical co-location is illustrated in Figs. 2 and 3. FLEXPART concentrations are output for atmospheric layers of roughly $1 \mathrm{~km}$ depth in the lower troposphere. Cloud retrievals associated with POLDER $P_{\mathrm{O}_{2}}$ pressures lying within the boundaries of each FLEXPART grid box are compared with the FLEXPART concentrations in that grid box. Clouds with $P_{\mathrm{O}_{2}}$ pressures between $800 \mathrm{hPa}$ and $900 \mathrm{hPa}$ are co-located with FLEXPART concentrations for FLEXPART grid boxes between $1 \mathrm{~km}$ and $2 \mathrm{~km}$; clouds with $P_{\mathrm{O}_{2}}$ pressures between $900 \mathrm{hPa}$ and $975 \mathrm{hPa}$ are colocated with FLEXPART concentrations for the grid boxes between $200 \mathrm{~m}$ and $1 \mathrm{~km}$.

The $0.5^{\circ} \times 0.5^{\circ}$ horizontal resolution of the FLEXPART model grid is considerably coarser than the $6 \mathrm{~km} \times 6 \mathrm{~km}$ satellite derived cloud property retrievals. To account for this difference in resolution, an averaging of cloud properties is performed for each FLEXPART three dimensional grid box, such that each grid box has only one set of cloud property values associated with it. Within each FLEXPART grid box, 


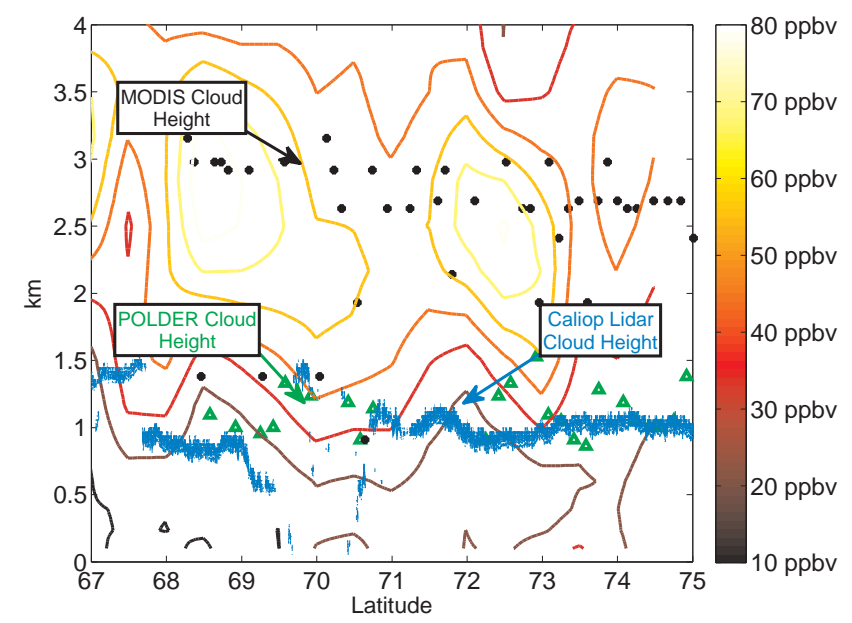

Fig. 1. Cloud top heights from the A-train instruments MODIS (black dots), POLDER (green $\Delta$ ) and CALIOP (blue dash), corresponding to a visually identified stratiform cloud deck in the White Sea, plotted with FLEXPART pollution tracer output (Contours) modeling anthropogenic and biomass burning $\mathrm{CO}$ emissions.

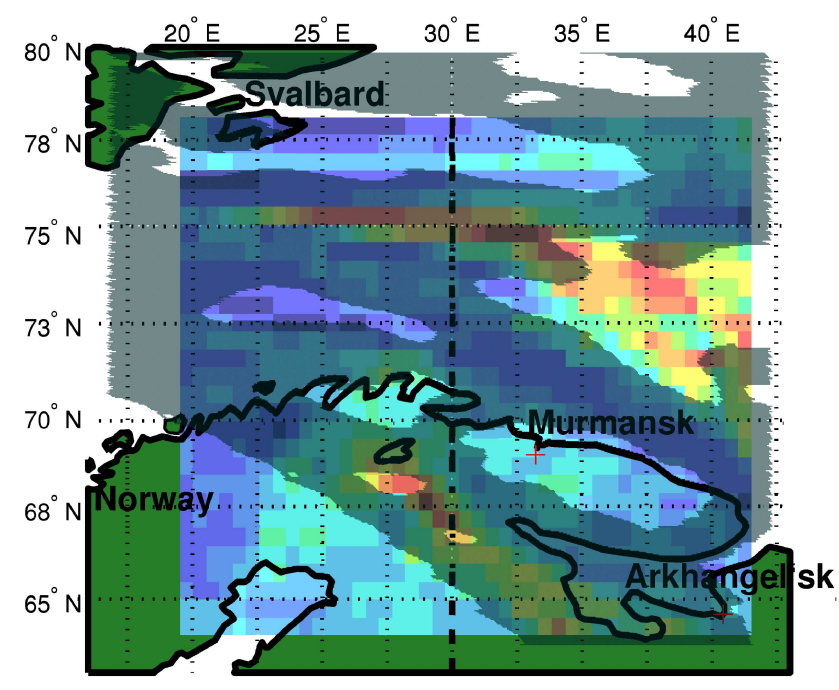

Fig. 2. Illustration of the horizontal and vertical co-location method, showing cloud with pressures from POLDER between $800 \mathrm{hPa}$ and $900 \mathrm{hPa}$ (gray shading) and average $\chi_{\mathrm{CO}}$ concentrations in ppbv for a layer between $1 \mathrm{~km}$ to $2 \mathrm{~km}$ altitude, colored shading. The dotted line is the location of the vertical transect shown in Fig. 3.

satellite retrieved properties are averaged together only if all retrievals of the cloud properties considered are successful. For example, if a cloud pixel has a successful cloud top height and effective radius retrieval, but the thermodynamic phase is undetermined, then none of the properties from that pixel are included in the analysis.

For the atmospheric heights below $800 \mathrm{hPa}$ used in this study, clouds are generally stratiform so that within a typical FLEXPART grid box, the variability in cloud properties

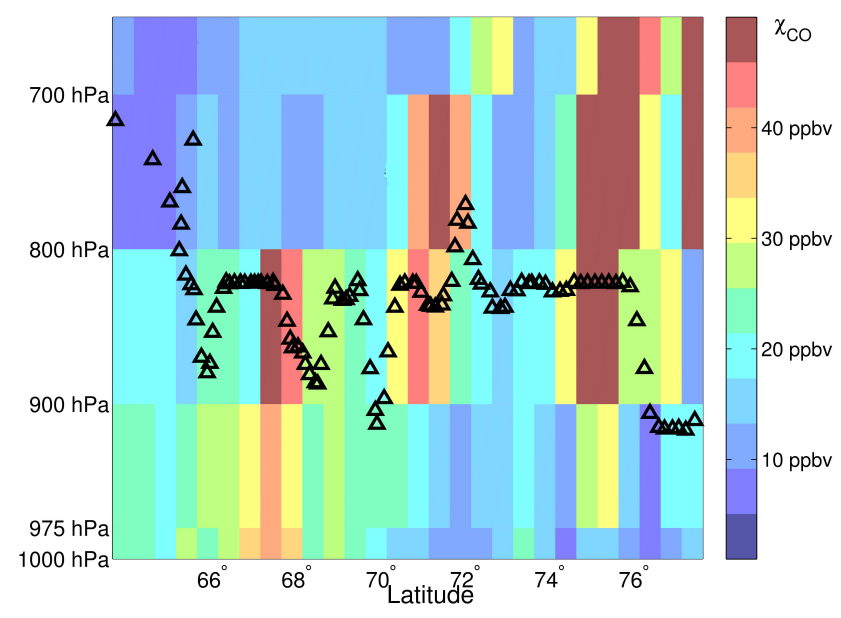

Fig. 3. Illustration of the vertical co-location method used for satellite cloud data and chemical tracer transport model output. The colors represent values of the $\mathrm{CO}$ pollution tracer for a vertical slice along the $30^{\circ}$ East meridian shown in Fig. 2. The $\Delta$ represent the POLDER retrieved cloud top pressure. After co-locating fields of cloud properties both horizontally and temporally, the cloud top pressure is matched to the output of the FLEXPART model that corresponds to the vertical location of the cloud.

is relatively small. However, about 7\% of FLEXPART grid boxes that were characterized by liquid clouds had less than $50 \%$ cloud coverage. These cases were not incorporated in the assessment of pollution-cloud interactions.

The co-location method is subject to some amount of error and uncertainty that will affect the relationships between $\chi_{\mathrm{CO}}$ and cloud properties. FLEXPART $\chi_{\mathrm{CO}}$ fields are only output every three hours, making the maximum temporal difference between observed cloud properties and pollution to be $1.5 \mathrm{~h}$. Advection errors from the ECMWF model grids and the parametrized turbulence are also possible. Anthropogenic emission inventories are based on data from previous years, making $\chi_{\mathrm{CO}}$ emission estimations another source of uncertainty. Furthermore, MODIS is only able to detect biomass burning under relatively cloud free conditions, possibly leading to underpredicted biomass burning $\chi_{\mathrm{CO}}$.

The advantage of co-locating satellite and FLEXPART fields is that it allows for high statistical coverage of the Arctic while allowing for comparison of pollution and clouds under similar meteorological regimes.

\section{Observations}

Figure 4 illustrates the general nature of the liquid clouds that were analyzed over the period between 20 March and 20 July 2008. More than $80 \%$ had cloud top temperatures below freezing, indicating supercooled water droplets. The characteristics of the retrieved cloud properties are, for the most part, consistent with prior in-situ measurements of Arctic 

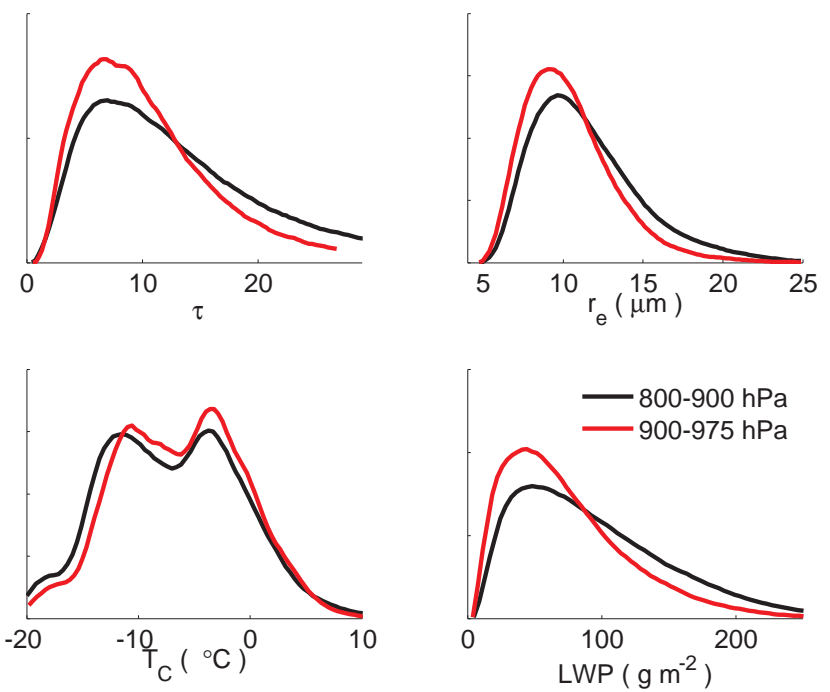

Fig. 4. Probability distribution functions for cloud optical depth $(\tau)$, effective radius $\left(r_{\mathrm{e}}\right)$, cloud top temperature $\left(T_{\mathrm{C}}\right)$ and liquid water path (LWP) for liquid, low-level Arctic clouds north of $65^{\circ} \mathrm{N}$, sampled over the period 20 March and 20 July 2008. For the vertical layers $800 \mathrm{hPa}$ to $900 \mathrm{hPa}$ and $900 \mathrm{hPa}$ to $975 \mathrm{hPa}$, respectively, there were 282,953 and $146,3730.5^{\circ} \times 0.5^{\circ}$ FLEXPART grid cells containing at least $50 \%$ cloud cover.

stratiform clouds (Curry et al., 1996; Shupe et al., 2006; de Boer et al., 2009). For clouds between $800 \mathrm{hPa}$ and $900 \mathrm{hPa}$, median [lower quartile, upper quartile] values for $\tau$ are 11.4 $[6.9,17.1], 82.7 \mathrm{gm}^{-2}[49.6,128.2]$ for LWP and $10.8 \mu \mathrm{m}$ [8.94, 13.33] for $r_{\mathrm{e}}$ and for clouds between $900 \mathrm{hPa}$ and $975 \mathrm{hPa}$ values are $\tau 10.0$ [6.6 14.5] for $\tau, 69 \mathrm{gm}^{-2}$ [41.7, 107.3] for LWP and $9.9 \mu \mathrm{m}[8.3,11.9]$ for $r_{\mathrm{e}}$.

Figure 5 shows an example of the calculation of $\mathrm{IE}_{\mathrm{re}}$ (Eq. 7), showing a comparison between FLEXPART $\chi_{\mathrm{CO}}$ fields and space-based retrievals of retrievals of $r_{\mathrm{e}}$ in lowlevel liquid clouds. It is clear from the scatter in this figure that pollution is not the primary control of cloud effective radius. Meteorology almost certainly plays a larger role. However, with sufficient statistics it is nonetheless apparent that there is a weak correlation between high levels of pollution and small effective radii.

Figure 6 shows the IE parameter (Eqs. 7-9) calculated for small bins $\left(2{ }^{\circ} \mathrm{C}\right)$ of cloud top temperature $T_{\mathrm{C}}$ and pressure for clouds with any retrieved value of LWP. As an additional constraint, Figure 6 also shows the IE parameter calculated for clouds with $\mathrm{LWP}<40 \mathrm{gm}^{-2}$ and $\mathrm{LWP}>40 \mathrm{gm}^{-2}$. The value of $\mathrm{LWP}<40 \mathrm{gm}^{-2}$ is chosen in order to isolate any dynamic feedbacks in clouds that may occur in clouds that are sufficiently thin to act as graybody emitters (Garrett et al., 2002). Clouds emitting as graybodies are hypothesized to be particularly susceptible to aerosol enhancements that create a climatologically significant warming effect (Garrett and Zhao, 2006; Lubin and Vogelmann, 2006; Mauritsen et al.,

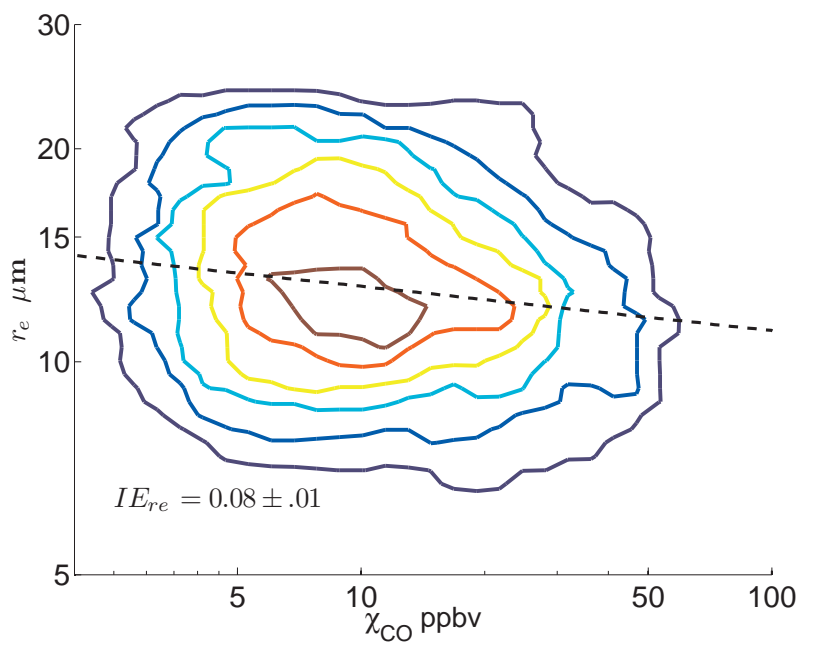

Fig. 5. Calculation of the IE parameter from a probability distribution of values of $r_{\mathrm{e}}$ and $\chi_{\mathrm{CO}}$ for liquid clouds in the Arctic with cloud top pressures between 800 and $900 \mathrm{hPa}$ and cloud top temperatures between 0 and $2^{\circ} \mathrm{C}$. Color scale indicates a higher density of values in linear intervals.

2011), and reductions in droplet effective radius can accelerate their development through a radiative-dynamic feedback mechanism (Garrett et al., 2009). Once the LWP exceeds $40 \mathrm{~g} \mathrm{~m}^{-2}$ the cloud is an approximate blackbody and cloud longwave emission is determined by temperature changes alone.

The plots show that, independent of pressure level, there is a general increase in values of IE with temperature until $T_{\mathrm{C}}$ reaches $0^{\circ} \mathrm{C}$, and then there is lower sensitivity at higher temperatures. Except for the coldest temperatures $\left(<-8^{\circ} \mathrm{C}\right)$, the sensitivity is larger for $\tau$ than for $r_{\mathrm{e}}$ because changes in $\chi_{\mathrm{CO}}$ are also associated with changes in LWP. Values of IE are smaller for graybody clouds with LWP $<40 \mathrm{gm}^{-2}$ than they are for thicker clouds.

For the span of this study, we find that biomass burning is clearly affecting the composition of the Arctic lower troposphere. Independent of potential temperature, it contributes to approximately half of the total FLEXPART CO concentrations when clouds are present. Figure 7 shows a clear association between larger values of $\chi_{\mathrm{CO}}$ and warmer potential temperatures $(\theta)$, where $\theta=T\left(P_{0} / P\right)^{2 / 7}$ and $P_{0}=1000 \mathrm{hPa}$. This is expected as most pollution originates from lower latitudes and is transported roughly isentropically into the Arctic (Stohl, 2006). For the low level Arctic clouds analyzed, the ratio of anthropogenic $\chi_{\mathrm{CO}}$ to $\chi_{\mathrm{CO}}$ from biomass burning is near unity, independent of potential temperature.

Here, the chemical composition and relative amounts of $\triangle \mathrm{CCN}$ for the different tracers are unknown and will influence the sensitivity of cloud properties to $\chi_{\mathrm{CO}}$. Prior studies suggest that the quantity of $\mathrm{CCN}$ per unit $\mathrm{CO}$ in pollution plumes is somewhat sensitive to whether the origins are from biomass burning or anthropogenic combustion. For example, 


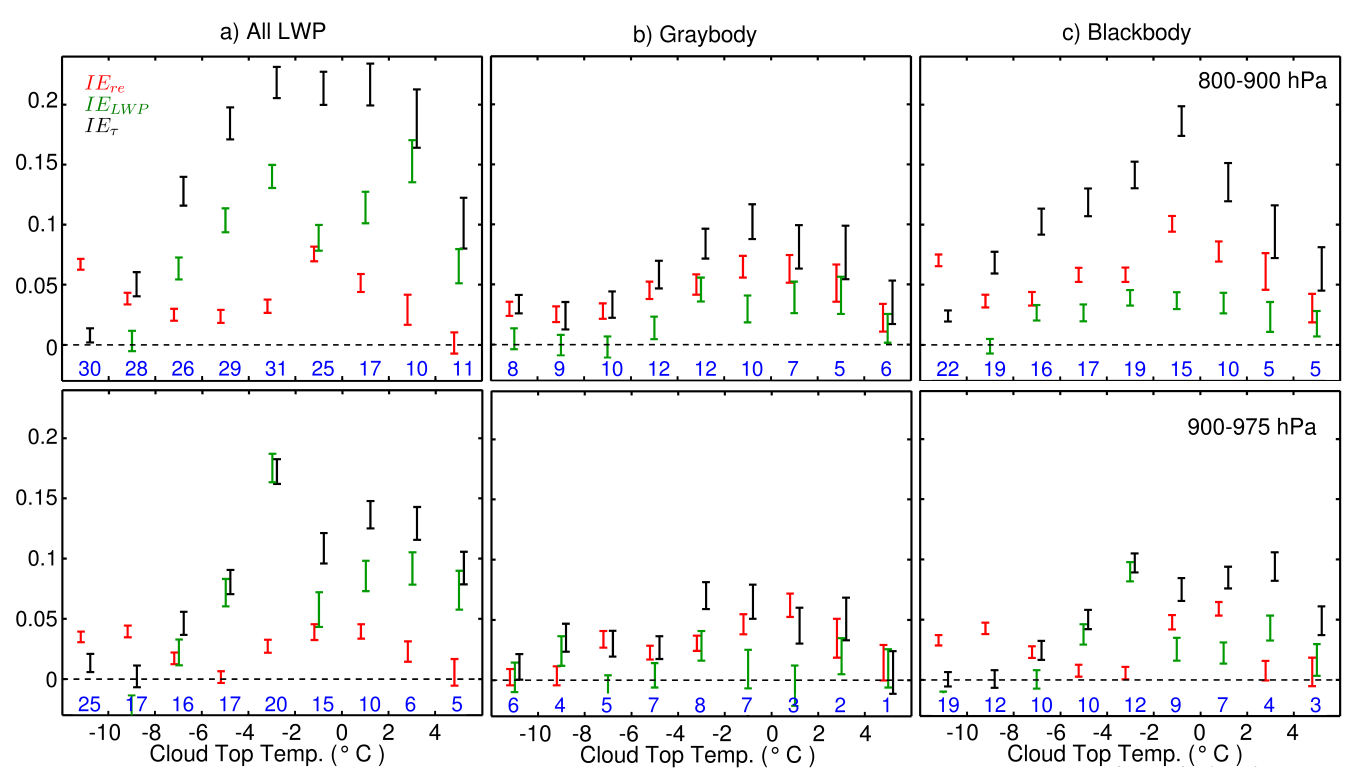

Fig. 6. IE parameter as a function of temperature calculated for liquid clouds $(\phi<50)$ north of $65^{\circ} \mathrm{N}$ from 20 March through $20 \mathrm{July}$ for the layers $800-900 \mathrm{hPa}$ (Row 1) and 900-975 hPa (Row 2). The bars indicate the $95 \%$ confidence limit in the calculation of IE. The figures are grouped according to; (a) all LWP, (b) graybody clouds with LWP $<40 \mathrm{gm}^{-2}$ or (c) blackbody clouds with $\mathrm{LWP}>40 \mathrm{gm}^{-2}$. Blue numbers indicate how many FLEXPART grid boxes containing clouds, in thousands, went into the calculation of the IE parameter.

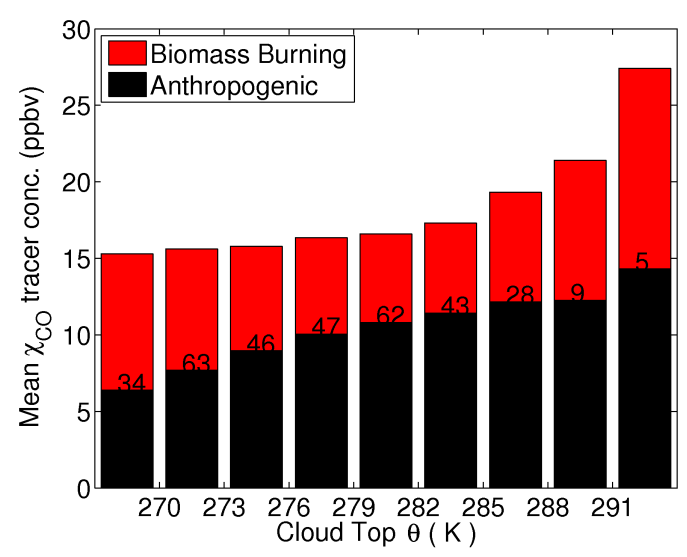

Fig. 7. Mean $\chi_{\mathrm{CO}}$ concentrations from anthropogenic and biomass burning sources, for clouds below $800 \mathrm{hPa}$, binned by cloud top potential temperatures shown on the bottom axis. Numbers, in thousands, indicate how many FLEXPART grid boxes with liquid clouds, at that potential temperature, were averaged together.

from in-situ measurements made near industrial mid-latitude sites in North America and Europe, the ratio of $\Delta \mathrm{CCN} / \triangle \mathrm{CO}$ is roughly $25 \pm 15 \mathrm{~cm}^{-3} \mathrm{ppb}^{-1}$ (Longley et al., 2005; Garrett et al., 2006). Comparable values of $40 \pm 20 \mathrm{~cm}^{-3} \mathrm{ppb}^{-1}$ can be computed for Arctic haze by relating observed ratios of droplet number concentrations to aerosol light scattering $(\sigma)$, which are $100 \pm 50 \mathrm{~cm}^{-3} \mathrm{Mm}^{-1}$ (Garrett et al., 2004), to observations from the same location of $\Delta \sigma / \Delta \mathrm{CO}$, which are $0.4 \pm 0.1 \mathrm{Mm} \mathrm{ppb}^{-1}$ (Garrett et al., 2010).

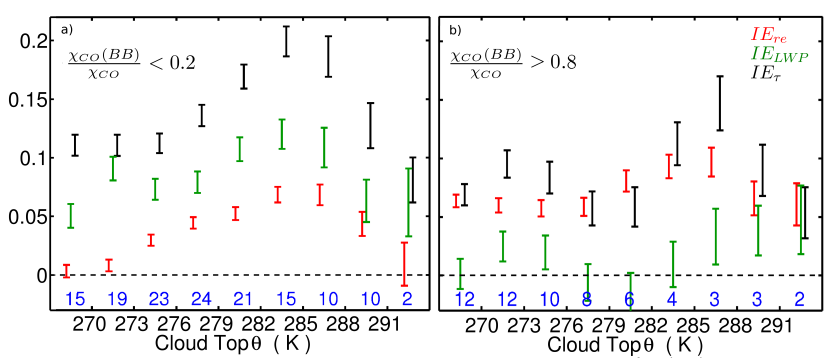

Fig. 8. As for Fig. 6 except the plots represent IE values plotted within $3 \mathrm{~K}$ bins in potential temperature for Arctic clouds coincident with biomass burning $\chi_{\mathrm{CO}}$ concentrations that are either $(\mathbf{a})>80 \%$ or (b) $<20 \%$ of the total $\chi_{\mathrm{CO}}$ concentrations.

Estimating values for the ratio $\Delta \mathrm{CCN} / \chi_{\mathrm{CO}}$ in biomass burning is more difficult because fuel type and fire size play a large role in the aerosol and mass concentration and solubility of it's particles (Rivera-Carpio et al., 1996; Reid et al., 2005). Large Siberian Boreal forest fires are a major but episodic source of aerosol during the spring and summer (Stohl, 2006). Unfortunately, this remote region is lacking in studies of the emission characteristics of biomass burning CCN (Paris et al., 2008). While regionally distinct, the scale and scope of Siberian Boreal forest fires is similar to large tropical fires that have been previously studied (Andreae et al., 2004; Vestin et al., 2007), where $\Delta \mathrm{CCN} / \Delta \mathrm{CO}$ values of $10 \pm 2 \mathrm{~cm}^{-3} \mathrm{ppb}^{-1}$ were observed near the active fires. 
The above survey suggests that $\Delta \mathrm{CCN} / \chi_{\mathrm{CO}}$ is potentially a factor of two (or more) larger for the anthropogenic tracer than it is for biomass burning plumes. To examine the sensitivity of clouds to differing pollution sources, we calculate values of IE for clouds where FLEXPART biomass burning $\chi_{\text {CO }}$ concentrations were either $>80 \%$ or $<20 \%$ of the total $\chi_{\mathrm{CO}}$ concentrations (Fig. 8).

Figure 8 shows that when biomass burning $\chi_{\mathrm{CO}}$ concentrations are relatively high, Arctic cloud properties show a sensitivity to pollution plumes that can be significant, particularly along isentropic surfaces between $282 \mathrm{~K}$ and $291 \mathrm{~K}$. Overall, however, biomass pollution plumes have a smaller effect on cloud properties per unit CO than do anthropogenic plumes.

\section{Discussion}

\subsection{Overall low-level Arctic cloud response to pollution plumes}

Calculated for low-level, liquid, stratiform clouds, north of $65^{\circ} \mathrm{N}$ Latitude, from the end of March through mid-July 2008, we obtain values for the IE parameter calculated with respect to a pollution tracer that range from 0.00 to 0.10 with respect to effective radius $\left(r_{\mathrm{e}}\right)$ and values of 0.00 to 0.21 with respect to optical depth $(\tau)$, with the largest values at temperatures near freezing.

For comparison, using ground based measurements obtained near Barrow Alaska, Garrett et al. (2004) found values of $\mathrm{IE}_{\mathrm{re}}$ for low-level liquid clouds in the range of 0.13 to 0.19 when the aerosol quantity considered was light scattering of sub-micron aerosol. Lihavainen et al. (2010) found $\mathrm{IE}_{\mathrm{re}}$ values of 0.2 to 0.3 in ground based measurements in Northern Finland and values of $\sim 0.1$ in satellite measurements for both $\mathrm{IE}_{\mathrm{re}}$ and $\mathrm{IE}_{\tau}$.

More globally, satellite based studies have obtained IE values ranging from 0.02 to 0.20 for continental clouds (Nakajima et al., 2001; Feingold et al., 2003; Lohmann and Feichter, 2005; Myhre et al., 2007) and 0.09 to 0.13 for oceanic clouds (Bréon et al., 2002; Sekiguchi et al., 2003; Kaufman et al., 2005; Myhre et al., 2007). Costantino and Bréon (2010) used space-based lidar to determine that African biomass burning aerosol layers were sometimes coincident with shallow marine stratocumulus clouds, and had IE values of 0.24. However, if there was no indication that aerosol layers were coincident with clouds, the IE value fell to 0.04 , illustrating the importance of vertical and horizontal co-location of aerosols and clouds in studies of the aerosol indirect effect.

Our analysis technique made many efforts to ensure clouds are compared with coincident pollution. However, limitations and uncertainties with the co-location technique, combined with advection errors in modeled FLEXPART pollu- tion levels, will act to reduce the correlation between cloud properties and $\chi_{\mathrm{CO}}$, leading to smaller values of IE.

Overall, the values of IE we calculated are smaller than those found in prior ground-based studies that directly observed coincident clouds and aerosols. This may be due in part to co-location errors. More importantly, however, comparisons were not made between cloud properties and an aerosol quantity, but rather with a passive pollution tracer $\chi_{\mathrm{CO}}$. Since concentrations of $\chi_{\mathrm{CO}}$ are independent of clouds and only affected by dilution and mixing, when the IE parameter is large, the implication is that values of the scavenging parameter $S$ (Eq. 5) are close to unity, and $\chi_{\mathrm{CO}}$ concentrations are associated with significant concentrations of $\mathrm{CCN}$ that have the capacity to perturb cloud properties.

It is no surprise then that the largest values of IE that we see are similar to those obtained in previous studies. However, we frequently find values of IE (and $S$ ) are substantially smaller, particularly when $T_{\mathrm{C}}$ is greater than $4{ }^{\circ} \mathrm{C}$. This suggests that at very warm temperatures wet scavenging is sufficiently efficient to limit the effects of pollution plumes on cloud properties. When temperatures are warm enough to support drizzle and rain processes, $\mathrm{CCN}$ are efficiently removed from the pollution plumes (Garrett et al., 2010), reducing the sensitivity of clouds to pollution plumes themselves. Effectively, the freezing point serves as a "scavenging point" of aerosol particles from pollution plumes.

What is a bit surprising is that there appears to be lowered sensitivity of clouds to pollution plumes with locally cold temperatures below $-6^{\circ} \mathrm{C}$ or below potential temperatures of about $278 \mathrm{~K}$. It is unclear why this should be so given that wet scavenging is unlikely to be particularly efficient due to low precipitation rates. Perhaps one explanation is that locally cold air masses are also associated with longer transport times from mid-latitude pollution source regions (Stohl, 2006). It is the time-integral of precipitation rates that ultimately determines the extent of wet scavenging. Additionally, cold potential temperatures will tend to be more associated with surface air that has increased susceptibility to dry deposition (Spackman et al., 2010). It may be that the "inverted-U" shape in the IE signature appears due to two competing effects: where surfaces of potential temperature are cold in the Arctic, precipitation is low but dry deposition is high and transport times are long; conversely, where Arctic potential temperature surfaces are warm, transport times are short but precipitation is high. Values of IE are at a maximum for temperatures where there is a minimum in the time integral of precipitation and dry deposition along transport pathways.

The broad statistical nature of the data sampling allows for the effects of possible dynamical and microphysical feedback processes to be evident in the analyses. Our dataset encompasses a broad time period and samples clouds at various points from their formation all the way until dissipation. Any feedback mechanisms occurring on short time scales will also be contributing to our results. If LWP is unaffected 
by pollution and $S$ is low, then the IE parameter calculated with respect to $r_{\mathrm{e}}$ and $\tau$ will be equal (see Eq. 3), and absent any dynamical feedbacks, IE values will range between 0 and 0.33 (Feingold, 2003). Here, we allow for feedbacks that would increase LWP and are usually neglected in aerosol indirect effect studies (Stevens and Feingold, 2009), the idea being that we are empirically fitting a slope to data that encompasses many phenomena in a complex system. Our data sampling occurs at various stages of a cloud's lifetime and over a long time period, so the results will include information about any dynamical feedback or precipitation process that may mediate the overall cloud response to pollution.

Figure 9, shows observed values of an enhancement factor (EF) representing the degree to which the cloud optical depth sensitivity $\mathrm{IE}_{\tau}$ exceeds the droplet effective radius sensitivity $\mathrm{IE}_{\mathrm{re}}$, based on results shown in Fig. 5, and plotted against potential temperature. When no constraint is made on LWP, values of EF are about four for values of $\theta>273 \mathrm{~K}$. The magnitude of the enhancement factor is smaller by about a factor of two when LWP is constrained to graybody clouds or blackbody clouds and for periods when biomass burning is greater than $80 \%$ total $\chi_{\mathrm{CO}}$. Note that any constraint on LWP is necessarily going to constrain the magnitude of any associated enhancement of $\mathrm{IE}_{\tau}$ : the sum of the enhancement factors for graybody and blackbody clouds is equal to that for all clouds. What is implied, however, is that the magnitude of the enhancement is not specific to clouds of any particular thickness.

Thus, our results suggest that LWP in Arctic low-level liquid clouds is more sensitive to mid-latitude pollution plumes than is $r_{\mathrm{e}}$, and therefore it is changes in LWP that are most important to the aerosol indirect effect. This is surprising, given that the most simple understanding of cloud physics is that values of LWP are determined primarily by thermodynamic constraints rather than aerosol concentrations. We cannot isolate an exact physical mechanism from the observations. One possibility, though, is that the observed IE enhancement at low LWP may be indicative of an infrared radiative feedback process that accelerates cloud development when clouds are thin and polluted (Garrett et al., 2009). More likely, given that the observed enhancement of $\mathrm{IE}_{\tau}$ is not specific to a particular range of cloud LWP, is that suppression of warm rain and drizzle by pollution aerosol may lead to a long term thickening of liquid stratiform clouds (Pincus and Baker, 1994; Wood, 2007; Stevens and Feingold, 2009; Mauritsen et al., 2011; Christensen and Stephens, 2011).

Also, a common but tenuous regime of supercooled liquid clouds precipitating ice is frequently observed in the Arctic (Curry et al., 1996; Intrieri et al., 2002; Shupe et al., 2006). Morrison et al. (2008) found in model simulations that elevated aerosol concentrations reduce riming processes in Arctic clouds and this can lead to increased LWP and cloud lifetime because ice particle growth is inhibited and suppresses ice crystal precipitation. By restricting our analysis to clouds with a radiatively determined phase index of $\phi \leq 50$, our study

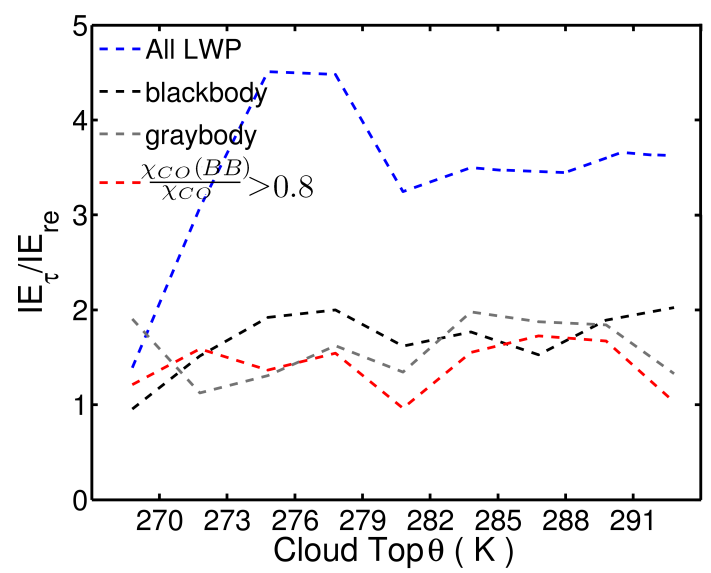

Fig. 9. Enhancement of $\mathrm{IE}_{\tau}$ over $\mathrm{IE}_{\mathrm{re}}$ as a function of potential temperature and LWP, for low-level liquid clouds in the Arctic from 20 March to 20 July 2008. The enhancements are plotted according to; (blue) all LWP, (gray) graybody clouds with LWP $<40 \mathrm{gm}^{-2}$, (black) blackbody clouds with LWP $>40 \mathrm{gm}^{-2}$ or (red) with biomass burning $(\mathrm{BB}) \chi_{\mathrm{CO}}>0.8$ of the total $\chi_{\mathrm{CO}}$ concentrations.

likely did not exclude liquid clouds that were precipitating ice. Thus, a precipitation feedback potentially could be contributing to our observation that cloud LWP is highly sensitivity to pollution, leading to large enhancement factors (EF) (Fig. 9).

A correlation between $\chi_{\mathrm{CO}}$ and LWP may also be expected for dynamical reasons. As a polluted, mid-latitude, and relatively warm air mass intrudes into the Arctic, it typically rises slantwise along a frontal surface above the colder Arctic dome. A cloud formed in such an air mass may be expected to be deeper than an average Arctic cloud considered in our analysis. The impact of this effect on our results should be minimized by having controlled for both cloud top temperature and pressure, and by considering only stratiform clouds with cloud tops below $2 \mathrm{~km}$, whose depth is clearly limited. Still, the effect may partly explain why $I_{\text {LWP }}$ values are larger than $\mathrm{IE}_{\mathrm{re}}$ values.

Further explanation for the observed sensitivity of LWP to the pollution tracer $\chi_{\mathrm{CO}}$ warrants further investigation. Perhaps, sensitivity studies using LES (Large Eddy Simulation) type cloud models may provide better insight into interpreting our observations. Similarly, if precipitation observations could be coupled with our cloud property observations, a more precise understanding of pollution-cloud interactions could be achieved, since precipitation determines wet scavenging and is closely tied to cloud microphysical properties.

\subsection{Cloud response to biomass burning}

Local aerosol sources, both natural and anthropogenic, may have the capacity to influence cloud properties (Quinn et al., 2008; Hirdman et al., 2010). However, the bulk of Arctic aerosol mass originates from outside the Arctic (Shaw, 
1995; Sirois and Barrie, 1999; Law and Stohl, 2007) and is well represented in FLEXPART by the anthropogenic and biomass burning tracers for $\chi_{\mathrm{CO}}$.

Figure 7 indicates that biomass burning contributes significantly to total pollution levels affecting low-level liquid clouds in the Arctic, consistent with results from several ARCPAC and ARCTAS related studies during April and July 2008 (Fuelberg et al., 2010). Unusually warm temperatures and reduced snow cover in the early spring favored pollution transport into the Arctic from Siberian wildfires and Kazakhstan agricultural burning (Warneke et al., 2009, 2010). Later in the summer, frequent biomass burning plumes were observed, often in elevated layers that originated from Eastern Siberian wildfires (Paris et al., 2008; Fuelberg et al., 2010).

Compared to when anthropogenic pollution dominates the plumes, plumes dominated by biomass burning exhibit a generally smaller response of cloud optical depth to pollution (Fig. 9). In particular, the response of LWP is near zero. One reason may be that biomass burning pollution plumes contain a smaller proportion of highly soluble $\mathrm{CCN}$ per unit $\mathrm{CO}$ than anthropogenic plumes. Biomass burning plumes typically contain $\mathrm{CCN}$ that are a mixture of soluble and insoluble particles, and they activate at a much larger range of supersaturations (Rivera-Carpio et al., 1996; Pradeep Kumar et al., 2003; Vestin et al., 2007).

The minimal enhancement in LWP, or values of $\mathrm{IE}_{\tau}$ over $\mathrm{IE}_{\text {re }}$ (Fig. 9), may point to other radiative characteristics of biomass burning aerosols dampening LWP feedback processes. For instance, our study did not preclude situations where additional biomass burning layers may be situated above the cloud layer. During the late spring and summer, these layers would absorb shortwave radiation and add an additional thermal forcing at cloud top (Brioude et al., 2009). The added warm layer may increase the atmospheric stability and favor low cloud development (Klein and Hartmann, 1993), or conversely, the added thermal flux may decrease the relative humidity and enhance evaporation, dissipating the cloud. While, we show an overall sensitivity of cloud properties to biomass burning plumes, a closer examination of the vertical profile and thermal characteristics of the biomass burning tracer is needed in order to constrain these possible effects.

\section{Conclusions}

This study has shown how an inert passive tracer can be used to quantify the indirect effects of anthropogenic and biomass burning pollution plumes on the properties of low-level liquid clouds in the Arctic north of $65^{\circ}$. Results show that, for a fairly narrow range of temperatures, the effects of pollution plumes on clouds is of a similar magnitude to those seen in previous satellite studies that looked explicitly at the effects of measured aerosols on clouds. The highest correlation be- tween cloud optical depth, droplet effective radius, and pollution occurs at temperatures near freezing.

However, there is a pronounced decrease in the sensitivity of clouds to pollution plumes at Arctic temperatures that are both warmer and colder than freezing, or alternatively Arctic potential temperatures that are warmer or colder than about $286 \mathrm{~K}$. We suggest that an explanation for this "inverted-U" phenomenon is the extent of time-integrated scavenging of aerosols along transport pathways from mid-latitudes. For Arctic air-masses with warmer temperatures, the decrease is due to more efficient wet scavenging of $\mathrm{CCN}$ in seasonally warm and moist air-masses. For Arctic air with colder temperatures, air rides closer to the surface and the transport time to the Arctic of air from mid-latitudes is prolonged, which increases potential exposure to precipitation and dry scavenging events.

We find also that biomass burning plumes interact less efficiently with clouds, per unit $\mathrm{CO}$, than do anthropogenic plumes, although their effects are still significant. Finally, independent of temperature, we find that the cloud optical depth has a substantially higher sensitivity to changes in pollution levels than can be explained by changes in cloud droplet effective radius alone, typically by a factor of four,. What this suggests is that pollution aerosols are activating precipitation suppression or some unknown dynamic feedback mechanism to increase liquid water path and cause large enhancements of the first indirect effect of aerosols on lowlevel Arctic liquid clouds.

Acknowledgements. T. Garrett was supported through National Science Foundation award ATM0649570. A. Stohl was supported by the Norwegian Research Council in the framework of the SUMSVAL project. The authors would like to thanks CNES and NASA for providing the POLDER and MODIS data, as well as the ICARE Data and Services Center for making the data and processing facilities available for part of these studies.

Edited by: J. Quaas

\section{References}

Ackerman, A. S., Kirkpatrick, M. P., Stevens, D. E., and Toon, O. B.: The impact of humidity above stratiform clouds on indirect aerosol climate forcing, Nature, 432, 1014-1017, doi:10.1038/nature03174, 2004.

Albrecht, B.: Aerosols, cloud microphysics and fractional cloudiness, Science, 245, 1227-1230, doi:10.1126/science.245.4923.1227, 1989.

Andreae, M. O., Rosenfeld, D., Artaxo, P., Costa, A., Frank, G. P., and Longo, K. M.: Smoking Rain Clouds over the Amazon, Science, 303, 1337-1342,doi:10.1126/science.1092779, 2004.

Avey, L., Garrett, T. J., and Stohl, A.: Evaluation of the aerosol indirect effect using satellite, tracer transport model, and aircraft data from the International Consortium for Atmospheric Research on Transport and Transformation, J. Geophys. Res., 112, D10S33,doi:10.1029/2006JD007581, 2007. 
Bréon, F. M., Tanré, D., and Generoso, S.: Aerosol effect on cloud droplet size monitored from satellite, Science, 295, 834-838, doi:10.1126/science.1066434, 2002.

Bréon, F. M. and Colzy, S.: Cloud detection from spaceborne POLDER instrument and validation against surface synoptic observations, J. Appl. Meteorol., 36, 777-785, doi:10.1175/15200450, 1999.

Brioude, J., Cooper, O. R., Feingold, G., Trainer, M., Freitas, S. R., Kowal, D., Ayers, J., Prins, E., Minnis, P., McKeen, S. A., Frost, G. J., and Hsie, E.-Y.: Effect of biomass burning on marine stratocumulus clouds off the California coast, Atmos. Chem. Phys., 9, 8841-8856, doi:10.5194/acp-9-8841-2009, 2009.

Buriez, J. C., Vanbauce, C., Parol, F., Goloub, P., Herman, M., Bonnel, B., Fouquart, Y., Couvert, P., and Seze, G.: Cloud detection and derivation of cloud properties from POLDER, International Journal of Remote Sensing, 18, 2785-2813, doi:10.1080/014311697217332, 1997.

Chang, F. and Coakley, J. A.: Relationships between Marine Stratus Cloud Optical Depth and Temperature Inferences from AVHRR Observations, J. Climate, 20, 2022-2036, doi:10.1175/JCLI4115.1, 2007.

Christensen, M. W. and Stephens, G. L.: Microphysical and macrophysical responses of marine stratocumulus polluted by underlying ships: Evidence of cloud deepening, J. Geophys. Res., 116, D03201, doi:10.1029/2010JD014638, 2011.

Costantino, L. and Bréon, F. M.: Analysis of aerosol-cloud interaction from multi-sensor satellite observations, Geophys. Res. Lett., 37, L11801, doi:10.1029/2009GL041828, 2010.

Curry, J. A., Rossow, W. B., and Randall, D.: Overview of Arctic Cloud and Radiation Characteristics., J. Climate, 9, 1731-1764, 1996.

de Boer, G., Eloranta, E. W., and Shupe, M. D.: Arctic Mixed-Phase Stratiform Cloud Properties from Multiple Years of SurfaceBased Measurements at Two High-Latitude Locations, J. Atmos. Sci., 66, 2874-2887, doi:10.1175/2009JAS3029.1, 2009.

Durkee, P. A., Noone, K. J., Ferek, R. J., Johnson, D. W., Taylor, J. P., Garrett, T. J., Hobbs, P. V., Hudson, J. G., Bretherton, C. S., Innis, G., Frick, G. M., Hoppel, W. A., O’Dowd, C. D., Russell, L. M., Gasparovic, R., Nielsen, K. E., Tessmer, S. A., Osborne, S. R., Flagan, R. C., Seinfeld, J. H., and Rand, H.: The Impact of Ship-Produced Aerosols on the Microstructure and Albedo of Warm Marine Stratocumulus Clouds: A Test of MAST Hypotheses 1 and 2, J. Atmos. Sci., 57, 2554-2569, 2000.

Feingold, G.: Modeling of the first indirect effect: Analysis of measurement requirements, Geophys. Res. Lett., 30, L1997, doi:10.1029/2003GL017967, 2003.

Feingold, G., Remer, L. A., Ramaprasad, J., and Kaufman, Y. J.: Analysis of smoke impact on clouds in Brazilian biomass burning regions: An extension of Twomey's approach, J. Geophys. Res., 106, 22907-22922, doi:10.1029/2001JD000732, 2001.

Feingold, G., Eberhand, W., and Veron, D. E.: First measurements of the Twomey indirect effect using ground based remote sensors., Geophys. Res. Lett., 30, L1287, doi:10.1029/2002GL016633, 2003.

Fisher, J. A., Jacob, D. J., Purdy, M. T., Kopacz, M., Le Sager, P., Carouge, C., Holmes, C. D., Yantosca, R. M., Batchelor, R. L., Strong, K., Diskin, G. S., Fuelberg, H. E., Holloway, J. S., Hyer, E. J., McMillan, W. W., Warner, J., Streets, D. G., Zhang, Q., Wang, Y., and $\mathrm{Wu}$, S.: Source attribution and interannual vari- ability of Arctic pollution in spring constrained by aircraft (ARCTAS, ARCPAC) and satellite (AIRS) observations of carbon monoxide, Atmos. Chem. Phys., 10, 977-996,doi:10.5194/acp10-977-2010, 2010.

Fougnie, B., Bracco, G., Lafrance, B., Ruffel, C., Hagolle, O., and Tinel, C.: PARASOL in-flight calibration and performance, Appl. Opt., 46, 5435-5451, doi:10.1364/AO.46.005435, 2007.

Frost, G. J., McKeen, S. A., Trainer, M., Ryerson, T. B., Neuman, J. A., Roberts, J. M., Swanson, A., Holloway, J. S., Sueper, D. T., Fortin, T., Parrish, D. D., Fehsenfeld, F. C., Flocke, F., Peckham, S. E., Grell, G. A., Kowal, D., Cartwright, J., Auerbach, N., and Habermann, T.: Effects of changing power plant $N O_{x}$ emissions on ozone in the eastern United States: Proof of concept, J. Geophys. Res., 111, D12306, doi:10.1029/2005JD006354, 2006.

Fuelberg, H. E., Harrigan, D. L., and Sessions, W.: A meteorological overview of the ARCTAS 2008 mission, Atmos. Chem. Phys., 10, 817-842, doi:10.5194/acp-10-817-2010, 2010.

Garrett, T. J. and Verzella, L. L.: An evolving history of Arctic aerosols, Bull. Amer. Meteorol. Soc., 89, 299-302, 2008.

Garrett, T. J. and Zhao, C.: Increased Arctic cloud longwave emissivity associated with pollution from mid-latitudes, Nature, 440, 787-789, doi:10.1038/nature04636, 2006.

Garrett, T. J., Radke, L. F., and Hobbs, P. V.: Aerosol Effects on Cloud Emissivity and Surface Longwave Heating in the Arctic., J. Atmos. Sci., 59, 769-778, doi:10.1175/1520-0469(2002)059, 2002.

Garrett, T. J., Zhao, C., Dong., X., Mace, G. G., and Hobbs, P. V.: Effects of varying aerosol regimes on low-level Arctic stratus, Geophys. Res. Lett., 31, L17105, doi:10.1029/2004GL019928, 2004.

Garrett, T. J., Avey, L., Palmer, P. I., Stohl, A., Neuman, J. A., Brock, C. A., Ryerson, T., and Holloway, J. S.: Quantifying wet scavenging processes in aircraft observations of nitric acid and CCN, J. Geophys. Res., 111, D23S51, doi:10.1029/2006JD007416, 2006.

Garrett, T. J., Maestas, M. M., Krueger, S. K., and Schmidt, C. T.: Acceleration of a radiative-thermodynamic cloud feedback influencing Arctic surface warming, Geophys. Res. Lett., 36, L19804, doi:10.1029/2009GL040195, 2009.

Garrett, T. J., Zhao, C., and Novelli, P.: Assessing the relative contributions of transport efficiency and scavenging to seasonal variability in Arctic aerosol, Tellus B., 62, 190-196, doi:10.1111/j.1600-0889.2010.00453.x, 2010.

Ghan, S., Schmid, B., Hubbe, J., Flynn, C., Laskin, A., Zelenyuk, D., Czizco, D., and Long, C. N.: Science Overview Document Indirect and Semi-Direct Aerosol Campaign (ISDAC) April 2008, Tech. rep., US Department of Energy, 2007.

Giglio, L., Descloitres, J., Justice, C. O., and Kaufman, Y. J.: An Enhanced Contextual Fire Detection Algorithm for MODIS, Remote Sensing of Environment, 87, 273-282, doi:10.1016/S00344257(03)00184-6, 2003.

Girard, E., Blanchet, J.-P., and Dubois, Y.: Effects of arctic sulphuric acid aerosols on wintertime low-level atmospheric ice crystals, humidity and temperature at Alert, Nunavut, Atmos. Res., 73, 131-148, doi:10.1016/j.atmosres.2004.08.002, 2005.

Goloub, P., Herman, M., Chepfer, H., Riedi, J., Brogniez, G., Couvert, P., and Seze, G.: Cloud thermodynamical phase classification from the POLDER spaceborne instrument, J. Geophys. Res., 105, 14747-14760, doi:10.1029/1999JD901183, 2000. 
Hirdman, D., Sodemann, H., Eckhardt, S., Burkhart, J. F., Jefferson, A., Mefford, T., Quinn, P. K., Sharma, S., StrÃm, J., and Stohl, A.: Source identification of short-lived air pollutants in the Arctic using statistical analysis of measurement data and particle dispersion model output, Atmos. Chem. and Phys., 10, 669-693, doi:10.5194/acp-10-669-2010, 2010.

Hobbs, P. V., Garrett, T. J., Ferek, R. J., Strader, S. R., Hegg, D. A., Frick, G. M., Hoppel, W. A., Gasparovic, R. F., Russell, L. M., Johnson, D. W., O'Dowd, C., Durkee, P. A., Nielsen, K. E., and Innis, G.: Emissions from Ships with respect to Their Effects on Clouds., J. Atmos. Sci., 57, 2570-2590, 2000.

Holz, R. E., Ackerman, S. A., Nagle, F. W., Frey, R., Dutcher, S., Kuehn, R. E., Vaughan, M. A., and Baum, B.: Global Moderate Resolution Imaging Spectroradiometer (MODIS) cloud detection and height evaluation using CALIOP, J. Geophys. Res., 113, D00A19, doi:10.1029/2008JD009837, 2008.

Huang, L., Gong, S. L., Jia, C. Q., and Lavoué, D.: Importance of deposition processes in simulating the seasonality of the Arctic black carbon aerosol, J. Geophys. Res., 115, D17207,doi:10.1029/2009JD013478, 2010.

Intrieri, J. M., Fairall, C. W., Shupe, M. D., Persson, P. O. G., Andreas, E. L., Guest, P. S., and Moritz, R. E.: An annual cycle of Arctic surface forcing at SHEBA, J. Geophys. Res., 107, C8039, doi:10.1029/2000JC000439, 2002.

Jacob, D. J., Crawford, J. H., Maring, H., Clarke, A. D., Dibb, J. E., Emmons, L. K., Ferrare, R. A., Hostetler, C. A., Russell, P. B., Singh, H. B., Thompson, A. M., Shaw, G. E., McCauley, E., Pederson, J. R., and Fisher, J. A.: The Arctic Research of the Composition of the Troposphere from Aircraft and Satellites (ARCTAS) mission: design, execution, and first results, Atmos. Chem. Phys., 10, 5191-5212, doi:10.5194/acp-10-5191-2010, 2010.

Kaufman, Y., Koren, I., Remer, L., Rosenfeld, D., and Rudich, Y.: The effect of smoke, dust, and pollution aerosol on shallow cloud development over the Atlantic Ocean, Proc. Natl. Acad. Sci., 102, 11207-11212, doi:10.1073/pnas.0505191102, 2005.

King, M. D., Platnick, S., Kaufman, D., Tanre, B. C., Menzel, W. P., Remer, L. A., Ackerman, S. A., and Gao, S.: Cloud and aerosol properties, precipitable water, and profiles of temperature and humidity from MODIS, IEEE, Trans. Geosci. Remote Sens., 41, 442-458, 2003.

King, M. D., Platnick, S. E., Hubanks, P. A., Arnold, T. G., and Wind, B.: Collection 005 Change Summary for the MODIS Cloud Optical Property Algorithm, NASA Tech Report, http: //modis-atmos.gsfc.nasa.gov/products_C005update.html, 2005.

Klein, S. A. and Hartmann, D. L.: The Seasonal Cycle of Low Stratiform Clouds., J. Climate, 6, 1587-1606, 1993.

Law, K. S. and Stohl, A.: Arctic Air Pollution: Origins and Impacts, Science, 315, 1537-1540, doi:10.1126/science.1137695, 2007.

Lihavainen, H., Kerminen, V.-M., and Remer, L. A.: Aerosol-cloud interaction determined by both in situ and satellite data over a northern high-latitude site, Atmos. Chem. Phys., 10, 1098710995, doi:10.5194/acp-10-10987-2010, 2010.

Lohmann, U. and Feichter, J.: Global indirect aerosol effects: a review, Atmos. Chem. Phys., 5, 715-737, doi:10.5194/acp-5-7152005, 2005.

Longley, I. D., Inglis, D. W. F., Gallagher, M. W., Williams, P. I., Allan, J. D., and Coe, H.: Using $\mathrm{NO}_{\mathrm{x}}$ and $\mathrm{CO}$ monitoring data to indicate fine aerosol number concentrations and emissions factors in three UK conurbations, Atmos. Environ., 39, 5157-5169, doi:10.1016/j.atmosenv.2005.05.017, 2005.

Lu, M. L. and Seinfeld, J. H.: Study of the Aerosol Indirect Effect by Large-Eddy Simulation of Marine Stratocumulus., J. Atmos. Sci., 62, 3909-3932,doi:10.1175/JAS3584.1, 2005.

Lubin, D. and Vogelmann, A. M.: A climatologically significant aerosol longwave indirect effect in the Arctic, Nature, 439, 453456, doi:10.1038/nature04449, 2006.

Matsui, H., Kondo, Y., Moteki, n., Takegawa, N., Sahu, L. K., Zhao, Y., Fuelberg, H. E., Sessions, W. R., Diskin, G., Blake, D. R., Wisthaler, A., and Koike, M.: Seasonal variation of the transport of black carbon aerosol from the Asian continent to the Arctic during the ARCTAS aircraft campaign, J. Geophys. Res., 116, D05202,doi:10.1029/2010JD015067, 2011.

Mauritsen, T., Sedlar, J., Tjernstrm, M., Leck, C., Martin, M., Shupe, M., Sjogren, S., Sierau, B., Persson, P. O. G., Brooks, I. M., and Swietlicki, E.: An Arctic CCN-limited cloud-aerosol regime, Atmos. Chem. Phys., 11, 165-173, doi:10.5194/acp-11165-2011, 2011.

Morrison, H. and Pinto, J. O.: Mesoscale modeling of springtime Arctic mixed-phase stratiform clouds using a new twomoment bulk microphysics scheme, J. Atmos. Sci., 62, 36833704, doi:10.1175/JAS3564.1, 2005.

Morrison, H., Pinto, O. J., Curry, J. A., and McFarquhar, G. M.: Sensitivity of modeled arctic mixed-phase stratocumulus to cloud condensation and ice nuclei over regionally varying surface conditions, J. Geophys. Res., 113, doi:10.1029/2007JD008729, 2008.

Myhre, G., Stordal, F., Johnsrud, M., Kaufman, Y. J., Rosenfeld, D., Storelvmo, T., Kristjansson, J. E., Berntsen, T. K., Myhre, A., and Isaksen, I. S. A.: Aerosol-cloud interaction inferred from MODIS satellite data and global aerosol models, Atmos. Chem. Phys., 7, 3081-3101, doi:10.5194/acp-7-3081-2007, 2007.

Nakajima, T., Higurashi, A., and Penner, J. E.: A possible correlation between satellite-derived cloud and aerosol microphysical parameters, Geophys. Res. Lett., 28, 1171-1174, doi:10.1029/2000GL012186, 2001.

Olivier, J. G. and Berdowski, J. J. M.: Global emission sources and sinks. In: Berdowski, J., Guicherit, R. and B.J. Heij (eds.) "The Climate System", Tech. rep., A. A. Balkema Publishers Swets Zeitlinger Publishers, Lisse, The Netherlands, 2001.

Paris, J., Ciais, P., Nédélec, P., Ramonet, M., Belan, B. D., Arshinov, M. Y., Golitsyn, G. S., Granberg, I., Stohl, A., Cayez, G., Athier, G., Boumard, F., and Cousin, J. M.: The YAK-AEROSIB transcontinental aircraft campaigns: new insights on the transport of $\mathrm{CO}_{2}, \mathrm{CO}$ and $\mathrm{O}_{3}$ across Siberia, Tellus B., 60, 551-568, doi:10.1111/j.1600-0889.2008.00369.x, 2008.

Pincus, R. and Baker, M. B.: Effect of precipitation on the albedo susceptibility of clouds in the marine boundary layer, Nature, 372, 250-252, doi:10.1038/372250a0, 1994.

Platnick, S., King, M. D., Ackerman, S. A., and Riedi, J.: The MODIS Cloud Products: Algorithms and Examples From Terra, IEEE Trans. Geosci. Remote Sensing, 41, 459-473, doi:10.1109/TGRS.2002.808301, 2003.

Pradeep Kumar, P., Broekhuizen, K., and Abbatt, J. P. D.: Organic acids as cloud condensation nuclei: Laboratory studies of highly soluble and insoluble species, Atmos. Chem. and Phys., 3, 509520, doi:10.5194/acp-3-509-2003, 2003.

Quaas, J., Boucher, O., and Bréon, F. M: Aerosol indirect effects in POLDER satellite data and the Laboratoire de Météorologie 
Dynamique-Zoom (LMDZ) general circulation model, J. Geophys. Res., 109, D08205, doi:10.1029/2003JD004317, 2004.

Quinn, P. K., Shaw, G., Andrews, E., Dutton, E. G., RuohoAirola, T., and Gong, S. L.: Arctic haze: current trends and knowledge gaps, Tellus B., 59, 99-114, doi:10.1111/j.16000889.2006.00238.x, 2007.

Quinn, P. K., Bates, T. S., Baum, E., Doubleday, N., Fiore, A. M., Flanner, M. G., Garrett, T. J., and Koch, D.: Short-lived pollutants in the Arctic: their climate impact and possible mitigation strategies, Atmos. Chem. Phys., 8, 1723-1735, doi:10.5194/acp8-1723-2008, 2008.

Radke, L. F., Coakley, J. A., and King, M. D.: Direct and Remote sensing of observations of the effects of ships on clouds, Science, 246, 1146, doi:10.1126/science.246.4934.1146, 1989.

Reid, J. S., Koppmann, R., Eck, T. F., and Eleuterio, D. P.: A review of biomass burning emissions, part II: Intensive physical properties of biomass burning particles, Atmos. Chem. Phys., 5, 799-825, doi:10.5194/acp-5-799-2005, 2005.

Riedi, J., Marchant, B., Platnick, S., Baum, B. A., Thieuleux, F., Oudard, C., Parol, F., Nicolas, J.-M., and Dubuisson, P.: Cloud thermodynamic phase inferred from merged POLDER and MODIS data, Atmos. Chem. Phys., 10, 11851-11865, doi:10.5194/acp-10-11851-2010, 2010.

Rivera-Carpio, C. A., Corrigan, C. E., Novakov, T., Penner, J. E., Rogers, C. F., and Chow, J. C.: Derivation of contributions of sulfate and carbonaceous aerosols to cloud condensation nuclei from mass size distributions, J. Geophys. Res., 101, 1948319494, doi:10.1029/95JD01077, 1996.

Sekiguchi, M., Nakajima, T., Suzuki, K., Kawamoto, K., and Rosenfeld, D.: A study of the direct and indirect effects of aerosols using global satellite data sets of aerosol and cloud parameters, J. Geophys. Res., 108, D4699, doi:10.1029/2002JD003359, 2003.

Shaw, G. E.: Evidence for a central Eurasian source area of Arctic haze in Alaska, Nature, 299, 815-818, 1982.

Shaw, G. E.: The Arctic Haze Phenomenon., Bull. Amer. Meteorol. Soc., 76, 2403-2414, 1995.

Shupe, M. D., Matrosov, S. Y., and Uttal, T.: Arctic MixedPhase Cloud Properties Derived from Surface-Based Sensors at SHEBA., J. Atmos. Sci., 63, 697-711, doi:10.1175/JAS3659.1, 2006.

Sirois, A. and Barrie, L. A.: Arctic lower troposphere aerosol trends and composition at Alert, Canada: 1980-1995, J. Geophys. Res., 104, 11599-11618, 1999.

Sodemann, H., Pommier, M., Arnold, S. R., Monks, S. A., Stebel, K., Burkhart, J. F., Hair, J. W., Diskin, G. S., Clerbaux, C., Coheur, P.-F., Hurtmans, D., Schlager, H., Blechschmidt, A.-M., Kristjánsson, J. E., and Stohl, A.: Episodes of cross-polar transport in the Arctic troposphere during July 2008 as seen from models, satellite, and aircraft observations, Atmos. Chem. Phys. Discuss., 10, 26361-26410, doi:10.5194/acpd-10-26361-2010, 2010.

Spackman, J. R., Gao, R. S., Neff, W. D., Schwarz, J. P., Watts, L. A., Fahey, D. W., Holloway, J. S., Ryerson, T. B., Peischl, J., and Brock, C. A.: Aircraft observations of enhancement and depletion of black carbon mass in the springtime Arctic, Atmos. Chem. Phys., 10, 9667-9680,doi:10.5194/acp-10-96672010, 2010.

Stevens, B. and Feingold, G.: Untangling aerosol effects on clouds and precipitation in a buffered system, Nature, 461, 607-613, doi:10.1038/nature08281, 2009.

Stohl, A.: POLARCAT White Paper, Tech. rep., NILU, http://www. polarcat.no/motivation, 2005.

Stohl, A.: Characteristics of atmospheric transport into the Arctic troposphere, J. Geophys. Res., 111, D11306, doi:10.1029/2005JD006888, 2006.

Stohl, A. and Thomson, D. J.: A Density Correction for Lagrangian Particle Dispersion Models, Bound.-Lay. Meteorol., 90, 155167, doi:10.1023/A:1001741110696, 1999.

Stohl, A., Forster, C., Eckhardt, S., Spichtinger, N., Huntrieser, H., Heland, J., Schlager, H., Wilhelm, S., Arnold, F., and Cooper, O.: A backward modeling study of intercontinental pollution transport using aircraft measurements, J. Geophys. Res., 108, D4370, doi:10.1029/2002JD002862, 2003.

Stohl, A., Forster, C., Frank, A., and Seibert, P.: Technical note: The Lagrangian particle dispersion model FLEXPART version 6.2, Tech. rep., NILU, 2005.

Stohl, A., Andrews, E., Burkhart, J. F., Forster, C., Herber, A., Hoch, S. W., Kowal, D., Lunder, C., Mefford, T., Ogren, J. A., Sharma, S., Spichtinger, N., Stebel, K., Stone, R., Ström, J., Tørseth, K., Wehrli, C., and Yttri, K. E.: Pan-Arctic enhancements of light absorbing aerosol concentrations due to North American boreal forest fires during summer 2004, J. Geophys. Res., 111, D22214, doi:10.1029/2006JD007216, 2006.

Stohl, A., Berg, T., Burkhart, J. F., Forster, C., Herber, A., Lunder, C., McMillan, W., Oltmans, S., Shiobara, M., Simpson, D., Solberg, S., Stebel, K., Strom, J., Treffeisen, R., Virkkunen, K., and Yttri, K. E.: Arctic smoke - record high air pollution levels in the European Arctic due to agricultural fires in Eastern Europe in spring 2006, Atmos. Chem. Phys., 7, 511-534, doi:10.5194/acp7-511-2007, 2007.

Stohl, A., Forster, C., Huntrieser, H., Mannstein, H., McMillan, W. W., Petzold, A., Schlager, H., and Weinzierl, B.: Aircraft measurements over Europe of an air pollution plume from Southeast Asia - aerosol and chemical characterization, Atmos. Chem. Phys., 7, 913-937, doi:10.5194/acp-7-913-2007, 2007.

Twomey, S.: The Influence of Pollution on the Shortwave Albedo of Clouds, J. Atmos. Sci., 34, 1149-1154, 1977.

Vestin, A., Rissler, J., Swietlicki, E., Frank, G. P., and Andreae, M. O.: Cloud-nucleating properties of the Amazonian biomass burning aerosol: Cloud condensation nuclei measurements and modeling, J. Geophys. Res., 112, D14201, doi:10.1029/2006JD008104, 2007.

Warneke, C., Bahreini, R., Brioude, J., Brock, C. A., de Gouw, J. A., Fahey, D. W., Froyd, K. D., Holloway, J. S., Middlebrook, A., Miller, L., Montzka, S., Murphy, D., Peischl, J., Ryerson, T. B., Schwarz, J., Spackman, J. R., and Veres, P.: Biomass burning in Siberia and Kazakhstan as an important source for haze over the Alaskan Arctic in April 2008, Geophys. Res. Lett., 36, L02813, doi:10.1029/2008GL036194, 2009.

Warneke, C., Froyd, K. D., Briode, J., and Stohl, A.: An important contribution to springtime Arctic aerosol from biomass burning in Russia, Geophys. Res. Lett., 37, L01801, doi:10.1029/2009GL041816, 2010

Warneke, C., Froyd, K. D., Brioude, J., Bahreini, R., Brock, C. A., Cozic, J., de Gouw, J. A., Fahey, D. W., Ferrare, R., Holloway, J. S., Middlebrook, A. M., Miller, L., Montzka, S. A., Schwarz, J. P., Sodemann, H., Spackman, R., and Stohl, A.: 
An important contribution to springtime Arctic aerosol from biomass burning in Russia, Geophys. Res. Lett., 37, L01801, doi:10.1029/2009GL041816, 2010.

Weisz, E., Li, J., Menzel, W. P., Heidinger, A. K., and Kahn, B. H.: Comparison of AIRS, MODIS, CloudSat and CALIPSO cloud top height retrievals, Geophys. Res. Lett., 34, L17811, doi:10.1029/2007GL030676, 2007.

White, P. W.: IFS Documentation, http://www.ecmwf.int, Tech. rep., ECMWF, Reading, UK, 2002.
Wood, R.: Cancellation of aerosol indirect effects in marine stratocumulus through cloud thinning, J. Atmos. Sci., 64, 26572669, doi:10.1175/JAS3942.1, 2007.

Xue, H. and Feingold, G.: Large eddy simulations of trade wind cumuli: Investigation of aerosol indirect effects, J. Atmos. Sci., 1605-1622, doi:10.1175/JAS3706.1, 2006. 